\title{
Study to assess knowledge attitude and practices of antenatal care among antenatal women attending outdoor clinic in tertiary care hospital
}

\author{
Neetu Ahirwar* \\ Department of Obstetrics and Gynecology, Gandhi Medical College, Bhopal, Madhya Pradesh, India
}

Received: 27 March 2018

Accepted: 31 March 2018

*Correspondence:

Dr. Neetu Ahirwar,

E-mail: neetuahirwarbharang@gmail.com

Copyright: () the author(s), publisher and licensee Medip Academy. This is an open-access article distributed under the terms of the Creative Commons Attribution Non-Commercial License, which permits unrestricted non-commercial use, distribution, and reproduction in any medium, provided the original work is properly cited.

\begin{abstract}
Background: Maternal mortality rate in India continues to be a national challenge despite of the various measures taken by the Indian government, Non profit organizations in and outside the country including the World Health Organization. To find out the gaps between the providers and beneficiaries we tried to find out what actually prevents our pregnant women to seek Regular Antenatal Care by evaluating their knowledge, attitudes and practices towards antenatal care.

Methods: All antenatal women attending outpatient clinic of department of obstetrics and gynae Gandhi medical college Bhopal over a period of one year were included in the study. Study group was of unbooked antenatal women and control group consisted of booked women at the hospital. All subjects were given a predesigned, pretested questionnaire to fill in their local language and the data thus obtained was analysed statistically.

Results: $86.16 \%$ subjects visited ANC clinic during first trimester, $66.33 \%$ knew correctly about frequency of antenatal visits, $97.50 \%$ knew about Tetanus immunization. Likewise, $78.33 \%$ had positive attitude towards antenatal checkups and early registration. Similarly, $70.4 \%$ took adequate antenatal care, $93.33 \%$ took iron folic acid tablets.

Conclusions: Thus, the study shows that the knowledge, attitude and practice of antenatal care is good in the booked subject the same is not the case in unbooked subjects coming to the hospital with complications or being referred to the hospital.
\end{abstract}

Keywords: Antenatal care, Attitude, Booked, Knowledge, Practices

\section{INTRODUCTION}

Introduction: Antenatal care is defined as a comprehensive antepartum care programme that involves co-ordinated approach to medical care and psychosocial support that optimally begins before conception and extends throughout antepartum period. Antenatal care (ANC) is a key strategy to decreasing maternal mortality in low-resource settings. ANC clinics provide resources to improve nutrition and health knowledge and promote preventive health practices.
Pregnant mothers contribute to a major vulnerable and priority group in any community, no less in India. According to the census 2011, maternal mortality rate in India accounts to an enormous figure of $212 .{ }^{1}$ Major causes include hemorrhage, obstructed labor, hypertension and other conditions. ${ }^{2}$ The reason being lack of proper antenatal care coverage and lack of awareness among mothers particularly from rural parts of India, contributing the major population, about the need of early 
registration and compliance with proper and regular ante natal checkups. ${ }^{2}$

Although numerous health programs are in vogue as run by the Government of India, State governments and also initiated by numerous Non Government Organizations (NGOs), the scenario of coverage of ante natal care in India is far from satisfactory. Poverty, lack of education and awareness are mainly responsible for this. In context of the present situation, it is obvious that proper antenatal care services can definitely alleviate the major burden of maternal and child mortality and morbidity in this country. As reflected from outcome from the private sector, good maternal and fetal outcome is directly related to good antenatal care. So, with following objectives, we are conducting this study in government set up to find out the lacunae in the antenatal care, which will help the government agencies to frame and implement policies there by reducing maternal and perinatal mortality and morbidity.

Objective of present study was to assess the knowledge of antenatal care among pregnant women attending out patient clinic, to assess the knowledge of antenatal care among pregnant women attending out patient clinic and to measure co-relation between knowledge and antenatal care.

\section{METHODS}

This is hospital based descriptive case control study on the antenatal women attending Outpatient clinic of department of obstetrics and gynae Gandhi Medical College, Bhopal, India with study duration of 1 year.

Study group includes all unbooked antenatal women and control group were antenatal women booked to department of obstetrics and gynae Gandhi medical college Bhopal.

Data collection was done using predesigned, pretested, structured questionnaire with prior verbal consent. The participants were traced prospectively and fetomaternal outcome was noted.

After data collection, statistical calculation and subsequently analysis was carried by using SPSS 16.0 version. Results has been presented in the forms of tables and graphs.

\section{RESULTS}

58.7 percent of study population was in 20-25 age group and due to a hospital-based study most of the subjects belong to urban population constituting 72.4 percent of the study.

In the study most of the subjects $(70.4 \%)$ were booked. This is probably because patient with booked status were under our follow up.
Table 1: Distribution of subjects as per demography.

\begin{tabular}{|c|c|c|}
\hline Age in years & No. $(n=600)$ & $\%$ \\
\hline$<20$ & 77 & 12.8 \\
\hline $20-25$ & 352 & 58.7 \\
\hline $26-30$ & 148 & 24.7 \\
\hline $3>30$ & 23 & 3.8 \\
\hline \multicolumn{3}{|l|}{ Place of residence } \\
\hline Rural & 165 & 27.6 \\
\hline Urban & 435 & 72.4 \\
\hline \multicolumn{3}{|l|}{ Religion } \\
\hline Hindu & 180 & 30.1 \\
\hline Muslim & 420 & 69.9 \\
\hline \multicolumn{3}{|c|}{ Education of subject } \\
\hline Illiterate & 103 & 17.1 \\
\hline Primary & 195 & 32.4 \\
\hline Middle school & 124 & 20.7 \\
\hline High school & 96 & 16.1 \\
\hline Graduate & 53 & 8.9 \\
\hline Post graduate & 29 & 4.8 \\
\hline \multicolumn{3}{|c|}{ Education of subject's husband } \\
\hline Illiterate & 63 & 10.5 \\
\hline Primary & 149 & 24.8 \\
\hline Middle school & 73 & 12.1 \\
\hline High school & 53 & 8.9 \\
\hline Secondary & 183 & $30 . .4$ \\
\hline Graduate & 55 & 9.2 \\
\hline Post graduate & 24 & 4.1 \\
\hline \multicolumn{3}{|c|}{ Occupation of subject } \\
\hline Housewife & 467 & 77.9 \\
\hline Skilled worker & 23 & 3.8 \\
\hline Unskilled worker & 110 & 18.3 \\
\hline
\end{tabular}

In this study $80.5 \%$ of subject had knowledge that pregnancy is confirmed by urine pregnancy test and scanning.

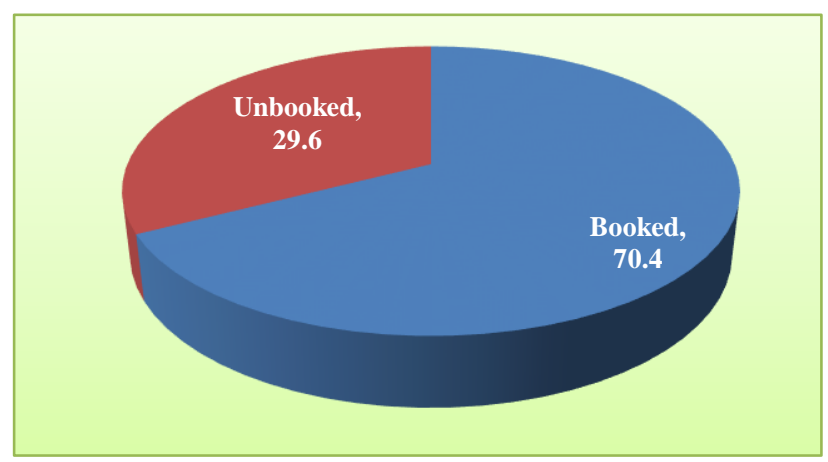

Figure 1: Distribution of subjects according to booking status.

$86.16 \%$ of subject had correct knowledge that a pregnant woman should visit a doctor after first missed period. $72.66 \%$ of subject had correct knowledge that fetal movement is first felt between 4th and 5th month of pregnancy. And $62.65 \%$ subjects had correct knowledge that fetal well being is known by regular antenatal check up. 
Table 2: Distribution of subjects according to knowledge of antenatal care.

\begin{tabular}{|c|c|c|c|c|}
\hline \multirow{2}{*}{ Knowledge about } & \multicolumn{2}{|c|}{ Correct } & \multicolumn{2}{|c|}{ Incorrect } \\
\hline & No. & $\%$ & No. & $\%$ \\
\hline Confirmation of pregnancy & 483 & 80.5 & 117 & 19.5 \\
\hline Time of $1^{\text {st }}$ visit to doctor & 517 & 86.16 & 83 & 13.83 \\
\hline Frequency of antenatal check up to $7^{\text {th }}$ month & 398 & 66.33 & 202 & 33.66 \\
\hline Frequency of antenatal check up between $7^{\text {th }}-9^{\text {th }}$ of pregnancy & 392 & 65.33 & 208 & 34.66 \\
\hline Frequency of antenatal check up after $9^{\text {th }}$ month of pregnancy & 382 & 63.66 & 118 & 36.33 \\
\hline Perception of $1^{\text {st }}$ fetal movement & 436 & 72.66 & 164 & 27.33 \\
\hline Knowledge about fetal well being & 375 & 62.65 & 225 & 37.50 \\
\hline Knowledge about warning signs during pregnancy & 385 & 64.16 & 215 & 35.83 \\
\hline Action to be taken in case of vaginal bleeding & 555 & 92.5 & 45 & 7.5 \\
\hline Examinations during antenatal check ups & 470 & 78.33 & 130 & 21.66 \\
\hline No. of TT immunizations & 585 & 97.50 & 15 & 2.50 \\
\hline Reasons for adequate diet during pregnancy & 495 & 82.50 & 105 & 17.5 \\
\hline Reasons for need of extra iron during pregnancy & 560 & 93.33 & 40 & 6.66 \\
\hline Necessity of folic acid during pregnancy & 304 & 50.66 & 296 & 49.33 \\
\hline
\end{tabular}

Table 3: Association of demographic profile with booking status.

\begin{tabular}{|c|c|c|c|c|c|c|}
\hline \multirow{2}{*}{ Demographic profile } & \multirow{2}{*}{ No. of subjects } & \multicolumn{2}{|c|}{ Booked } & \multicolumn{2}{|c|}{ Unbooked } & \multirow{2}{*}{ p-value } \\
\hline & & No. & $\%$ & No. & $\%$ & \\
\hline \multicolumn{7}{|l|}{ Age in years } \\
\hline$<20$ & 77 & 54 & 70.12 & 23 & 29.8 & \\
\hline $20-25$ & 352 & 242 & 68.75 & 110 & 31.25 & \\
\hline $26-30$ & 148 & 100 & 67.56 & 48 & 32.4 & \\
\hline$>30$ & 23 & 16 & 69.56 & 7 & 30.4 & \\
\hline \multicolumn{7}{|l|}{ Place of residence } \\
\hline Rural & 165 & 100 & 60.60 & 65 & 39.4 & \multirow{2}{*}{$0.001^{*}$} \\
\hline Urban & 435 & 310 & 71.26 & 125 & 28.7 & \\
\hline \multicolumn{7}{|l|}{ Religion } \\
\hline Hindu & 180 & 128 & 70.4 & 52 & 28.9 & \multirow{2}{*}{$0.02 *$} \\
\hline Muslim & 420 & 270 & 64.28 & 150 & 35.7 & \\
\hline \multicolumn{7}{|l|}{ Education of subjects } \\
\hline Illiterate & 103 & 51 & 49.5 & 52 & 50.4 & \multirow{6}{*}{$0.0001 *$} \\
\hline Primary & 195 & 137 & 70.2 & 58 & 29.7 & \\
\hline Middle school & 124 & 87 & 70.15 & 37 & 29.8 & \\
\hline High School & 96 & 90 & 93.75 & 6 & 6.25 & \\
\hline Graduate & 53 & 53 & 100.0 & 0 & 0.0 & \\
\hline Post graduate & 29 & 29 & 100.0 & 0 & 0.0 & \\
\hline \multicolumn{7}{|c|}{ Education of subject's husband } \\
\hline Illiterate & 63 & 32 & 50.8 & 31 & 49.2 & \multirow{7}{*}{$0.0001 *$} \\
\hline Primary & 149 & 90 & 60.4 & 59 & 39.6 & \\
\hline Middle school & 73 & 50 & 68.5 & 23 & 31.5 & \\
\hline High School & 53 & 34 & 64.2 & 19 & 35.8 & \\
\hline Secondary & 183 & 138 & 75.41 & 45 & 24.6 & \\
\hline Graduate & 55 & 40 & 72.72 & 15 & 27.3 & \\
\hline Post graduate & 24 & 23 & 95.83 & 1 & 4.16 & \\
\hline \multicolumn{7}{|l|}{ Occupation of subjects } \\
\hline Housewife & 467 & 315 & 67.45 & 152 & 32.5 & \multirow{3}{*}{0.03} \\
\hline Skilled worker & 23 & 20 & 83.0 & 3 & 13.0 & \\
\hline Unskilled worker & 110 & 72 & 65.45 & 38 & 34.5 & \\
\hline
\end{tabular}

$64.18 \%$ of subjects had knowledge about warning signs during pregnancy and $92.5 \%$ knew that they should report to a doctor in case of vaginal bleeding during antenatal period. $78.33 \%$ of subjects had knowledge 
regarding essential examinations during antenatal check up. $97.50 \%$ of study subjects had correct knowledge regarding tetanus immunisation. $82.50 \%$ of subjects had correct knowledge that adequate diet during pregnancy helps for growth and development of fetus. $93.33 \%$ of subjects had knowledge that extra iron is needed during pregnancy to prevent anaemia. While only $50.66 \%$ of subject had knowledge that folic acid is needed during pregnancy to prevent anaemia and birth deformities.

Table 4: Association of knowledge about maternal care with booking status.

\begin{tabular}{|c|c|c|c|c|c|c|}
\hline \multirow{3}{*}{ Knowledge about } & \multirow{3}{*}{$\begin{array}{l}\text { No. of } \\
\text { subjects }\end{array}$} & \multicolumn{4}{|c|}{ Correct knowledge } & \multirow{3}{*}{ p-value ${ }^{1}$} \\
\hline & & \multicolumn{2}{|c|}{ Booked } & \multicolumn{2}{|c|}{ Unbooked } & \\
\hline & & No. & $\%$ & No. & $\%$ & \\
\hline Confirmation of pregnancy & 483 & 348 & 72.04 & 135 & 27.9 & $0.0001 *$ \\
\hline Time of $1^{\text {st }}$ visit of antenatal care to doctor & 517 & 371 & 71.60 & 146 & 28.2 & $0.0001 *$ \\
\hline Frequency of antenatal check up before 7 th month & 398 & 295 & 74.12 & 103 & 25.9 & $0.0001 *$ \\
\hline Frequency of antenatal check up between $7^{\text {th }}-9^{\text {th }}$ of pregnancy & 392 & 295 & 75.25 & 97 & 24.7 & $0.0001 *$ \\
\hline Frequency of antenatal check up after $9^{\text {th }}$ of pregnancy & 382 & 300 & 78.53 & 82 & 21.4 & $0.0001 *$ \\
\hline Percept ion of $1^{\text {st }}$ fetal movement & 439 & 328 & 74.71 & 111 & 25.3 & $0.0001 *$ \\
\hline Knowledge about fetal well being & 375 & 268 & 71.46 & 107 & 28.5 & $0.002 *$ \\
\hline Knowledge about warning signs during pregnancy & 385 & 264 & 68.57 & 121 & 31.4 & 0.33 \\
\hline Action to be taken in case of vaginal bleeding & 555 & 384 & 68.19 & 171 & 30.8 & $0.03 *$ \\
\hline Examinations during antenatal check ups & 470 & 320 & 68.08 & 150 & 31.9 & 0.84 \\
\hline No. of TT immunizations & 585 & 388 & 66.32 & 197 & 33.7 & $0.0001 *$ \\
\hline Reasons for adequate diet during pregnancy & 495 & 350 & 70.70 & 145 & 29.3 & $0.003^{*}$ \\
\hline Reasons for need of extra iron during pregnancy & 560 & 390 & 69.64 & 170 & 30.4 & 0.91 \\
\hline Necessity of folic acid during pregnancy & 304 & 225 & 74.03 & 134 & 79 & $0.001 *$ \\
\hline
\end{tabular}

${ }^{1}$ Chi-square test, *Significant

There is significant association of booking status with place of residence, education of subject and subject's husband, occupation of subject's.

There is significant association between place of residence and booking status. Among urban people 71.26 $\%$ of subjects were booked and $28.7 \%$ unbooked. While booking is $60.6 \%$ in rural subject. There is also significant association between booking status and education status of subjects. Graduate and post graduate subjects are $100 \%$ booked but among illiterate only $50.8 \%$ of subjects were booked, those educated upto primary school among them $60.4 \%$ were booked but $39.6 \%$ were unbooked.

There is significant association between the knowledge about fetal well being, Tetanus Toxoid immunization, need for adequate diet and necessity of folic acid during pregnancy with booking status of subjects.

\section{DISCUSSION}

A descriptive case control study was carried out in Department of Obstetrics and Gynaecology, Gandhi Medical College, Bhopal, Madhya Pradesh, India for a period of 1 year.

Objective of study was to assess the knowledge of antenatal care among antenatal women attending outpatient clinic. To determine the association between the knowledge of antenatal women attending OPD with selected demographic variables.

In present study $58.7 \%$ of respondents belonged to age group 20-245years. In a study conducted by Rozliza et al majority of the respondents $(46.2 \%)$ were from age group 20-29 year. ${ }^{3}$ study conducted by Shirin $\mathrm{S}$ et al mean age of women was $33.5 \pm 10.4$ years. ${ }^{4}$ In study conducted by Alam AY et al the mean age of women was $29.57 \pm 7.1$ years. ${ }^{5}$

This may be explained by the fact that mothers between the ages of 15 to 24 years do not have enough information on maternal healthcare services, while those of age 35 to 44 years take things for granted.

Similar study conducted by Manas $\mathrm{P}$ et al most of the respondents were more than 25 years. $^{6}$

In present study most of the subjects were belongs to age group 20-25 years among this age group $68.75 \%$ were booked while $31.2 \%$ were unbooked (p value $<0.87$ ). There by, the age group of 25-35 appears to be most careful regarding antenatal care.

In present study there is significant association of booking status with place of residence, education of 
subject and subject's husband, occupation of subject's husband.

Most of the subjects were Muslims i.e. $69.9 \%$ out of them $64.28 \%$ of subjects were booked, and $35.7 \%$ were unbooked while $30.1 \%$ were Hindu $70.4 \%$ of them were booked while $28.9 \%$ of them unbooked. This shows Hindu's are practicing more antenatal care.

In present study $72.4 \%$ were resident of urban areas and $27.6 \%$ from rural areas. This is because our study is an Urban hospital based study. In contrast, study conducted by Padam Singh et al $63.7 \%$ respondent belongs to rural areas while $36.3 \%$ belongs to urban areas, probably they were catering to predominantly rural population.

In present study $32.4 \%$ of subjects were educated upto primary and half of the total subjects were not educated beyond high school. In similar study conducted by Rozliza et al $42.3 \%$ didn't received any primary or secondary education. In similar study conducted by Alam AY et al $69.5 \%$ of subjects were illiterate.

In present study most of the $(32.4 \%)$ subjects were educated upto primary 1 out of them $70.2 \%$ were booked. 8.95 and $4.8 \%$ of total subjects were graduate and post graduate respectively and all were booked. So, this shows there is significant impact of level of education on their acceptance and utilisation of antenatal care.

In present study $30.4 .4 \%$ of subject's husbands were educated upto senior secondary school. In a similar study conducted by Padam Singh et al $27.3 \%$ of subject's husband were educated to higher secondary school. ${ }^{7}$

The present study reported that there was a significant effect of subject's husband education on booking status of subjects $27 \%$ of total subject's husband were educated upto secondary school and $75.41 \%$ of this group were booked. And booking was $95.83 \%$ in post graduate husband. As husband is the head of family so he acts as motivator for subject for practicing antenatal care. Study conducted by Simkhada B et al also shows significant association of utilisation of antenatal services with husband's education status. ${ }^{8}$

In traditional societies where restrictions are placed on women's freedom of movement and contact with unrelated men, a husband's attitude toward prenatal care may be an important factor in determining whether prenatal care is received. While men's approval of formal prenatal care may be culturally patterned along ethnic and religious lines, there may also be significant variation within ethno-religious groups based on levels of education, exposure to modern healthcare practices, individual interpretations of religious values and adherence to traditional beliefs. It is, therefore, expected that having a husband who approves of prenatal care significantly increases the likelihood that a woman uses prenatal care, irrespective of the husband's background characteristics.

In present study maximum respondent $77.9 \%$ were housewives. Because most of the women of India especially in this part of country are housewives. This is in line with the study conducted by Alam AY et al $81.5 \%$ of respondent were housewives.

Similar result was found in study conducted by Sonia Shirin et al i.e. $96 \%$ were housewives. Study found significant relationship between husband's occupation and booking conducted by Ziyo FY et al. ${ }^{9}$

In present study $79 \%$ of total subjects had correct knowledge about confirmation pregnancy and early registration i.e. in first trimester and $71 \%$ of them utilized antenatal services adequately ( $p$ value $<0.01$ ). Similar results were seen in a study conducted by Rosliza AM et al $73.1 \%$ of subjects had knowledge regarding early registration. ${ }^{3}$

About $66.33 \%$ of subjects had correct knowledge regarding the adequate frequency of antenatal check-ups during pregnancy trimester wise, out of them $71.6 \%$ took adequate antenatal care and $72.66 \%$ of total subjects had correct knowledge regarding perception of fetal movement and among this $70 \%$ of subjects utilises antenatal services.

$72.66 \%$ of total subjects had correct knowledge regarding perception of fetal movement and among this $70 \%$ of subjects utilises antenatal services.

In present study $70 \%$ of total subjects had correct knowledge about TT immunisation, requirement of adequate diet and need for folic acid during pregnancy. Among them $74.54 \%$ utilised adequate antenatal services. These results show positive relationship with booking status.

$64.16 \%$ of total subjects had correct knowledge about warning signs during pregnancy in contrast to study conducted by Shirin $S$ et al where they found that respondent's knowledge about warning signs during pregnancy was poor. ${ }^{4}$

Knowledge regarding warning signs during pregnancy and need for extra iron during pregnancy shows no relationship with booking status.

Therefore, adequate knowledge has positive relationship with booking status. This in turn results in better maternal and fetal outcome as evidenced in many other studies.

\section{CONCLUSION}

Improving maternal health is one of the millennium development goal. Antenatal women form a large section of our society. Pregnancy and birth of a baby is generally 
a celebrated event in India. However, in many families, these events may become a symbol of sorrow and grief where mothers depart from their babies and families because of inadequate and poor or nil maternal health services provided to these innocent mothers. These maternal deaths could be prevented by applying simple preventive measures.

There is a need to target certain groups of population such as rural, uneducated and economically backward and find the way through which the attendance of ANC visit can be increased. Moreover, strong political commitment, coordination between program implementing agencies, monitoring, evaluation and follow up of the programs will be needed.

Funding: No funding sources

Conflict of interest: None declared

Ethical approval: The study was approved by the Institutional Ethics Committee

\section{REFERENCES}

1. Population Census 2011. Available at https://www.census2011.co.in

2. Yohannes B, Tarekegn M, Paulos W. Mothers' utilization of antenatal care and their satisfaction with delivery services in selected public health facilities of wolaita zone, Southern Ethiopia. IntJ Scien Technol Res. 2013 Feb;2(2):74-85.

3. Rozilza AM, Muhamad HJ. Knowledge, Attitude and Practices on Antenatal care among Orang Asli women of Jempol, Negeri Sembilan, Malaysian. J Public Health Med. 2011;11(2):13-21

4. Shirin S. Knowledge, attitude and practice of maternal health care amongst the married women in rural area of Bangladesh. Ibrahim Med Coll J. 2011;5(1):13-6.

5. Alam AY, Qureshi AA, Adil MM, Ali H. Comparative study of knowledge, attitude and practices among antenatal care facilities utilizing and non-utilizing women. J Pak Med Assoc. 2005 Feb 1;55(2):53-6.

6. Roy MP, Mohan U, Singh SK, Singh VK, Srivastava AK. Determinants of utilization of antenatal care services in rural Lucknow, India. Journal of family medicine and primary care. 2013 Jan;2(1):55.

7. Singh P, Yadav RJ. Antenatal care of pregnant women in India. Indian J Community Med. 2000:7.

8. Simkhada B, Teijlingen ER, Porter M, Simkhada P. Factors affecting the utilization of antenatal care in developing countries: systematic review of the literature. J Advanc Nurs. 2008 Feb;61(3):244-60.

9. Yousuf F, Haider G, Shaikh RB. Factors for inaccessibility of antenatal care by women in Sindh. J Ayub Med Coll Abbottabad. 2010 Dec $1 ; 22(4): 187-9$.

Cite this article as: Ahirwar N. Study to assess knowledge attitude and practices of antenatal care among antenatal women attending outdoor clinic in tertiary care hospital. Int J Reprod Contracept Obstet Gynecol 2018;7:1754-9. 